\title{
Study of correlation between maternal body mass index with maternal and perinatal outcome
}

\section{Chandrashekhar Tharihalli*, Varija Thathagari}

\begin{abstract}
Department of Obstetrics and Gynecology, Vijayanagara Institute of Medical Sciences, Ballari- 583104, Karnataka,
\end{abstract} India

Received: 21 October 2016

Accepted: 17 November 2016

\section{*Correspondence:}

Dr. Chandrashekhar Tharihalli,

E-mail: cstobg@gmail.com

Copyright: (c) the author(s), publisher and licensee Medip Academy. This is an open-access article distributed under the terms of the Creative Commons Attribution Non-Commercial License, which permits unrestricted non-commercial use, distribution, and reproduction in any medium, provided the original work is properly cited.

\begin{abstract}
Background: To study the correlation between maternal body mass index (BMI) with maternal and perinatal outcome in women admitted to labour ward in Department of OBG, VIMS, Ballari.

Methods: This observation study was conducted in Department of OBG, VIMS, Ballari for a period of one year between 1st October 2014 to 30th September 2015. All women admitted to labour ward with full term singleton pregnancy were included in the study. The cases were classified into four groups as under-weight (BMI <20kg/m2), normal (BMI 20-24.9kg/m2), over-weight (BMI 25-29.9kg/m2) and obese (BMI >30kg/m2). The maternal and perinatal outcome noted and studied in the above groups.

Results: A total of 500 cases were included during the study period of one year, out of which $15 \%$ were underweight, $68 \%$ were normal BMI, $12 \%$ were over-weight and $5 \%$ cases were obese $(\mathrm{BMI}>30 \mathrm{~kg} / \mathrm{m} 2)$. The patients with low BMI had higher incidence of low birth weight (40\%) and perinatal deaths. Increased BMI category was associated with higher incidence of PIH (25-28\%), operative deliveries (50-68\%), PPH (12\%), microsomal babies (32\%), low APGAR (24\%) and perinatal deaths (12\%).

Conclusions: Adverse maternal and perinatal outcomes are significantly related to extremes of BMI categories and least complications were seen in normal BMI group.
\end{abstract}

Keywords: BMI, Macrosomia, Obese, LSCS, Low birth-weight, PIH, PPH, Under-weight

\section{INTRODUCTION}

One of the most important noticeable factors in pregnancy is gain in weight. Weight gain in pregnancy is directly related to the birth weight of the foetus. Maternal malnutrition is the most important underlying determinant factor in adverse maternal and foetal outcome. In our country, due to extreme socio-economic status pattern underweight and obesity are prevalent among pregnant women. Body Mass Index (BMI) or Quetelet Index is defined as the body mass (weight) divided by the square of the body height and is calculated by formula "weight in $\mathrm{kg} /$ height in meter". 1,2
The present study was conducted to examine the correlation between the maternal BMI with maternal and perinatal outcome in view of $\mathrm{PIH}$, operative deliveries, PPH, Low birth-weight, macrosomia, low APGAR at birth and perinatal mortality.

\section{METHODS}

This observational study was conducted in Department of OBG, VIMS, Ballari for a period of one year between 1st October 2014 to 30th September 2015. 
All women admitted to Labour Ward, Department of OBG, VIMS, Ballari who meets the inclusion criteria were selected for the study.

\section{Inclusion criteria}

All women admitted to labour ward with full-term singleton pregnancy in labour.

\section{Exclusion criteria}

- Pre-term deliveries

- Post-dated pregnancies

- Multi-foetal gestation

- Previous caesarean section

- Foetal malpresentations and malpositions

- History of medical disorders

Ethical clearance was obtained from VIMS Institutional Ethical Committee (IEC) and details of all cases are entered in the prescribed proforma after taking informed consent. Height and weight of the patients were recorded by means of standard methodology described by Lohman et al. ${ }^{1}$

BMI was calculated (weight in $\mathrm{kg} / \mathrm{height}$ in $\mathrm{meter}^{2}$ ) and cases were classified into four groups accordingly.

Table 1: BMI classification.

\begin{tabular}{|ll|}
\hline Under-weight & BMI $<20 \mathrm{~kg} / \mathrm{m}^{2}$ \\
\hline Normal & BMI $20-24.9 \mathrm{~kg} / \mathrm{m}^{2}$ \\
\hline Over-weight & BMI $25-29.9 \mathrm{~kg} / \mathrm{m}^{2}$ \\
\hline Obese & BMI $>30 \mathrm{~kg} / \mathrm{m}^{2}$ \\
\hline
\end{tabular}

Maternal outcome was studied in the form of PIH, Caesarean deliveries (LSCS) and PPH, and perinatal outcome was studied in the view of Low birth weight, macrosomia, low APGAR at birth and at 5 mins and perinatal deaths.

\section{Statistical analysis}

The outcome of the study was compare by Chi Square test and $\mathrm{P}$ value of $<0.05$ was regarded as statistically significant.

\section{RESULTS}

A total of 500 cases were included in the study during one year of study period out of which $15 \%$ were underweight (75 cases), $68 \%$ were normal BMI (340 cases), $12 \%$ were over-weight (60 cases) and $5 \%$ cases were obese (25 cases).

\section{Maternal outcome}

The incidence of PIH was highest in obese group (28\%) and overweight group (25\%) compared to normal BMI group $(6.17 \%)$ and underweight group $(2.6 \%)$.
Table 2: Characteristics of study group.

\begin{tabular}{|lll|}
\hline Parameters & Mean & N \\
\hline Age $($ Years $)$ & 21.8 & 500 \\
\hline Weight $(\mathrm{kg})$ & 56.5 & 500 \\
\hline Height $(\mathrm{cm})$ & 152.6 & 500 \\
\hline BMI $\left(\mathrm{kg} / \mathrm{m}^{2}\right)$ & 23.25 & 500 \\
\hline Birth Weight $(\mathrm{kg})$ & 2.76 & 500 \\
\hline
\end{tabular}

Table 3: BMI versus PIH.

\begin{tabular}{|c|c|c|c|c|c|}
\hline BMI & PIH & & $\begin{array}{l}\text { No } \\
\text { PIH }\end{array}$ & & $P$ value \\
\hline & $\mathrm{F}$ & $\%$ & $\mathrm{~F}$ & $\%$ & \\
\hline $\begin{array}{l}\text { Under-weight } \\
(n=75)\end{array}$ & 2 & 2.7 & 73 & 97.3 & $<0.001$ \\
\hline $\begin{array}{l}\text { Normal } \\
(n=340)\end{array}$ & 21 & 6.2 & 319 & 93.8 & \\
\hline $\begin{array}{l}\text { Over-weight } \\
(\mathrm{n}=60)\end{array}$ & 15 & 25.0 & 45 & 75.0 & \\
\hline Obese $(n=25)$ & 7 & 28.0 & 18 & 72.0 & \\
\hline
\end{tabular}

Majority of cases $(68 \%)$ required operative delivery in obese group followed by overweight group (50\%). 38 women underwent LSCS in normal BMI group (11.17\%).

Table 4: BMI versus type of delivery.

\begin{tabular}{|lllllll|}
\hline BMI & LSCS & \multicolumn{3}{l|}{ FNVD } & \multicolumn{1}{l|}{ P } \\
\hline & $\mathrm{F}$ & $\%$ & $\mathrm{~F}$ & $\%$ & \\
\hline $\begin{array}{l}\text { Under- } \\
\text { weight } \\
(\mathrm{n}=75)\end{array}$ & 10 & 13.3 & 65 & 86.7 & $<0.001$ \\
\hline $\begin{array}{l}\text { Normal } \\
(\mathrm{n}=340)\end{array}$ & 38 & 11.2 & 302 & 88.8 & \\
\hline $\begin{array}{l}\text { Over- } \\
\text { weight } \\
(\mathrm{n}=60)\end{array}$ & 30 & 50.0 & 30 & 50.0 & \\
\hline $\begin{array}{l}\text { Obese } \\
(\mathrm{n}=25)\end{array}$ & 17 & 68.0 & 8 & 32.0 & \\
\hline
\end{tabular}

Table 5: BMI versus post-partum haemorrhage.

\begin{tabular}{|llllll||}
\hline & PMI & \multicolumn{3}{c|}{$\begin{array}{l}\text { No } \\
\text { PPH }\end{array}$} & P value \\
\hline & F & $\%$ & F & $\%$ & \\
\hline $\begin{array}{l}\text { Under- } \\
\text { weight } \\
(n=75)\end{array}$ & 2 & 2.7 & 73 & 97.3 & $<0.001$ \\
\hline $\begin{array}{l}\text { Normal } \\
(n=340)\end{array}$ & 8 & 2.4 & 332 & 97.6 & \\
\hline $\begin{array}{l}\text { Over- } \\
\text { weight } \\
(n=60)\end{array}$ & 6 & 10.0 & 54 & 90.0 & \\
\hline $\begin{array}{l}\text { Obese } \\
(n=25)\end{array}$ & 3 & 12.0 & 22 & 88.0 & \\
\hline
\end{tabular}


Table 6: BMI versus birth weight of baby.

\begin{tabular}{|llllll|}
\hline BMI & LBW & \multicolumn{3}{c|}{$\begin{array}{l}\text { Normal birth } \\
\text { weight }\end{array}$} & P value \\
\hline & F & $\%$ & F & $\%$ & \\
\hline Under-weight $(\mathrm{n}=75)$ & 30 & 40.0 & 45 & 60.0 & $<0.001$ \\
\hline Normal(n=340) & 20 & 5.9 & 320 & 94.1 & \\
\hline Over-weight $(\mathrm{n}=60)$ & 11 & 18.3 & 49 & 81.7 & \\
\hline Obese $(\mathrm{n}=25)$ & 4 & 16.0 & 21 & 84.0 & \\
\hline
\end{tabular}

Table 7: BMI versus macrosomia.

\begin{tabular}{|c|c|c|c|c|c|}
\hline BMI & \multicolumn{2}{|c|}{ Macrosomia } & \multicolumn{2}{|c|}{ Normal } & \multirow[t]{2}{*}{ P value } \\
\hline & $\mathrm{F}$ & $\%$ & $\mathrm{~F}$ & $\%$ & \\
\hline Under-weight $(n=75)$ & 0 & 0.0 & 75 & 100 & $<0.001$ \\
\hline Normal $(n=340)$ & 3 & 0.9 & 337 & 99.1 & \\
\hline Over-weight $(\mathrm{n}=60)$ & 10 & 16.7 & 50 & 83.3 & \\
\hline Obese $(n=25)$ & 8 & 32.0 & 17 & 68.0 & \\
\hline
\end{tabular}

Table 8: BMI versus Apgar score.

\begin{tabular}{|llllll|}
\hline BMI & Low Apgar & \multicolumn{3}{c|}{ Normal Apgar } & P value \\
\hline & $\mathrm{F}$ & $\%$ & $\mathrm{~F}$ & $\%$ & \\
\hline Under-weight $(\mathrm{n}=75)$ & 13 & 17.3 & 62 & 82.7 & $<0.001$ \\
\hline Normal $(\mathrm{n}=340)$ & 8 & 2.4 & 332 & 97.6 & \\
\hline Over-weight $(\mathrm{n}=60)$ & 8 & 13.3 & 52 & 86.7 & \\
\hline Obese $(\mathrm{n}=25)$ & 6 & 24.0 & 19 & 76.0 & \\
\hline
\end{tabular}

Table 9: BMI versus perinatal outcome.

\begin{tabular}{|c|c|c|c|c|c|}
\hline BMI & $\begin{array}{l}\text { Perinatal } \\
\text { deaths }\end{array}$ & & Alive & & P value \\
\hline & F & $\%$ & $\mathrm{~F}$ & $\%$ & \\
\hline Under-weight $(\mathrm{n}=75)$ & 7 & 9.3 & 68 & 90.7 & $<0.001$ \\
\hline Normal $(n=340)$ & 6 & 1.8 & 334 & 98.2 & \\
\hline Over-weight (n=60) & 6 & 10.0 & 54 & 90.0 & \\
\hline Obese $(n=25)$ & 3 & 12.0 & 22 & 88.0 & \\
\hline
\end{tabular}

The risk of PPH was higher in increased BMI group (10$12 \%)$ compared to normal and underweight group (2.3$2.6 \%)$.

\section{Perinatal outcome}

Low birth weight babies $(<2500 \mathrm{~g})$ were seen more in underweight category (40\%) followed by overweight group (30\%). Least number of LBW cases was seen in normal BMI group $(5.88 \%)$.

Macrosomia (Birth weight $>4000 \mathrm{~g}$ ) was seen in $32 \%$ of obese group followed by overweight group (16\%). Only 3 cases of macrosomia babies $(0.8 \%)$ were noted in normal BMI group whereas no macrosomia documented in underweight group.

In the present study low APGAR at birth was seen in maximum cases at both extremes of BMI. $24 \%$ of obese group had low APGAR followed by $17.3 \%$ of underweight group.

Perinatal deaths were highest in obese group (12\%) and overweight group (10\%) followed by underweight group (9.3\%). Only $1.76 \%$ of deaths noted in normal BMI group. 


\section{DISCUSSION}

The present study shows that both the extremes of BMI group predispose the women to adverse maternal and perinatal outcome.

In our study, the incidence of PIH was significantly associated with increasing maternal obesity, similar findings were reported by Kabir et al, Sahu et al and Deepika $\mathbf{J}$ et al and Jain $\mathrm{P}$ et al. ${ }^{2-5}$

The present study has observed that highest number of women has undergone caesarean section in obese group $(68 \%)$ and overweight group (50\%). This study correlates with the study conducted by Bhattacharya $S$ et al, Deepika $\mathrm{J}$ et al and Jain $\mathrm{P}$ et al. ${ }^{4-6}$

In the current study obese and overweight group had increased incidence of PPH (10-12\%) compared to normal BMI and underweight group (2.6-2.8) which correlates with the studies done by Sebire NJ et al, Bhattacharya $\mathrm{S}$ et al and Deepika J et al. ${ }^{4,5}$

The occurrence of low birth weight babies was more in both the extreme groups. $40 \%$ of LBW babies were seen in underweight babies followed by overweight and obese group (16-18\%) which correlates well with studies conducted by Sahu et al, Kabir et al, Deepika J et al and Jain $\mathrm{P}$ et al. ${ }^{2-5}$

In the present study there's strong association of obesity and risk of macrosomic babies which accounts for $32 \%$ cases. Similar association was reported by Deepika et al, Jain $\mathrm{P}$ et al and Sebire NJ et al. ${ }^{4,5,7}$

In the current study low APGAR at birth was seen more in obese group (24\%) and also in underweight group $(17.3 \%)$ which is in accordance with Jain $\mathrm{P}$ et al and Pillai $\mathrm{S}$ et al studies. ${ }^{5,8}$

In the present study series perinatal deaths were more in obese (12\%) and overweight group (10\%) followed by underweight group $(9.3 \%)$, which correlates with the study conducted by Jain $\mathrm{P}$ et al. ${ }^{5}$

\section{CONCLUSION}

The present study clearly shows that both the extremes of maternal BMI groups are associated with adverse maternal and perinatal outcomes. It also states that complications are least in normal BMI individuals.

\section{Funding: No funding sources}

Conflict of interest: None declared

Ethical approval: The study was approved by the Institutional Ethics Committee

\section{REFERENCES}

1. Lohman TG, Roche AF, Martorell R, Anthropometric standardisation reference manul Champaign: Human Kinetics Book; 1988.

2. Kabira W, Raynor BD, Obstetric outcomes associated with increase in BMI category during pregnancy. Am J Obstet Gynecol. 2004;191(3):928-38.

3. Sahu MT, Agarwal A, Das V. Impact of maternal body mass index on obstetric outcome. J Obstet Gynaecol Res. 2007;33(5):655-9.

4. Deepika J, Rakesk K, Veena C. effect of body mass index on pregnancy outcomes in nulliparous woman delivering singleton babies: observational study; Journal of Obstet Gynec of India. 2012;62(4):429-31.

5. Jain P, Joshi T, Kural MR. Relation of early pregnancy BMI with maternal and foetal outcome: a prospective study. International Journal of Science and Nature. 2013;4(4):642-5.

6. Bhattacharya S, Campbell DM, Liston WA. effect of body mass index on pregnancy outcomes in nulliparous women delivering singleton babies. BMC Public Health. 2007;7;168.

7. Sebire NJ, Jolly M, Harris JP. Maternal obesity and pregnancy outcome. A study of 287,213 pregnancies in London. Int J Obes. 2001;25:1175-82.

8. Scott-Pillai R, Spence D, Cardwell CR. the impact of body mass index on maternal and neonatal outcomes: a retrospective study in a UK obstetric population, 20042011. BJOJ. 2013;120(8):932-9.

Cite this article as: Tharihalli $\mathrm{C}$, Thathagari V. Study of correlation between maternal body mass index with maternal and perinatal outcome. Int J Reprod Contracept Obstet Gynecol 2017;6:164-7. 